3 Michio Takagi ${ }^{1}$, Kotchakorn T.sriwong ${ }^{1}$, Ayaka Masuda ${ }^{1}$, Nozomi Kawaguchi ${ }^{1}$, Shusuke Fukui ${ }^{1}$, Huong

4 Le Viet Lan ${ }^{1}$, Dai-ichiro Kato ${ }^{2}$, Takashi Kitayama ${ }^{3}$, Mikio Fujiii, Afifa Ayu Koesoema ${ }^{5}$, Tomoko

$5 \quad$ Matsuda $^{1 *}$

6

\section{Immobilization of Baeyer-Villiger monooxygenase from acetone grown Fusarium sp.}

\section{${ }^{1}$ Department of Life Sciences and Technology, School of Life Science and Technology, Tokyo Institute of} Technology, 4259 Nagatsuta-cho, Midori-ku, Yokohama, 226-8501, Japan

${ }^{2}$ Graduate School of Science and Engineering, Kagoshima University

1-21-35 Korimoto, Kagoshima 890-0065 Japan

k0035454@kadai.jp

${ }^{3}$ Faculty of Agriculture, Kindai University 3327-204, Nakamachi, Nara, Japan

kitayama@nara.kindai.ac.jp

${ }^{4}$ School of Pharmacy, International University of Health and Welfare

2600-1 Kitakanemaru, Ohtawara, Tochigi, Japan

mfujii@iuhw.ac.jp

${ }^{5}$ Research Institute for Interdisciplinary Science (RIIS), Okayama University

700-8530 3-1-1 Tsushimanaka, Kita-ku, Okayama-shi, Japan

Corresponding author:

Tomoko Matsuda (tmatsuda@bio.titech.ac.jp, tel/fax +81-45-924-5757)

\section{Abstract}

Objective

A novel biocatalyst for Baeyer-Villiger oxidations is necessary for pharmaceutical and chemical industries, so this study aims to find a Baeyer-Villiger monooxygenase (BVMO) and to improve its stability by immobilization.

Results

Acetone, the simplest ketone, was selected as the only carbon source for the screening of microorganisms with a BVMO. A eukaryote, Fusarium sp. NBRC 109816, with a BVMO (FBVMO), was isolated from a soil sample. $F \mathrm{BVMO}$ was overexpressed in $E$. coli and successfully immobilized by the organic-inorganic nanocrystal formation method. The immobilization improved the thermostability of FBVMO. Substrate 
specificity investigation revealed that both free and immobilized $F \mathrm{BVMO}$ were found to show catalytic activities not only for Baeyer-Villiger oxidation of ketones to esters but also for oxidation of sulfides to sulfoxides. Furthermore, a preparative scale reaction using immobilized FBVMO was successfully conducted.

Conclusions

FBVMO was discovered from an environmental sample, overexpressed in E. coli, and immobilized by the organic-inorganic nanocrystal formation method. The immobilization successfully improved its thermostability.

\section{Keywords}

Baeyer-Villiger monooxygenase, Fusarium sp. NBRC 109816, immobilization, thermostability

\section{Introduction}

The Baeyer-Villiger oxidation (BVO), the transformation of an acyclic ketone or cyclic ketone and chemical industries. However, commonly used oxidants for BVO, such as meta-chloroperbenzoic acid ( $m$ CPBA) and trifluoroperacetic acid (TFPAA) (Know 1993), are potentially explosive. Moreover, the stoichiometric amounts of hazardous reagent, a peroxyacid, is converted to a carboxylic acid, producing chemical waste. Therefore, an effort to use environmentally benign oxidants such as $\mathrm{H}_{2} \mathrm{O}_{2}$ and $\mathrm{O}_{2}$ has been made (Bryliakov 2017; Liu et al. 2020). On the other hand, biocatalysts have been considered to be sustainable catalysts (Matsuda 2017; Dong et al. 2018; Sheldon and Woodley 2018; Birolli et al. 2019; Wu et al. 2020; Koesoema et al. 2020). For biocatalytic BVO, Baeyer-Villiger monooxygenase (BVMO) can use oxygen in the air as an oxidant, producing water as a byproduct (Fig. 1), so that the reactions are not explosive (Morii et al. 1999; Kyte et al. 2004; Rehdorf et al. 2007; Franceschini et al. 2012; Leipold et al. 2012, 2013; Fürst et al. 2017, 2019; Nguyen et al. 2017; Fordwour et al. 2018; Woo et al. 2018). Approximately a hundred of BVMOs (Fürst et al. 2019) such as Acinetobacter cyclohexanone monooxygenase (AcCHMO)(Donoghue et al. 1976; Chen et al. 1988; Bong et al. 2018), Pseudomonas putida 2,5-diketocamphane monooxygenase (2,5-DKCMO) (Cassimjee et al. 2014), and Thermocrispum municipale cyclohexanone monooxygenase (TmCHMO) (Delgove et al. 2019) have been used for biocatalytic BVO. However, comparing other kinds of biocatalysts such as lipases and carbonyl reductases, the number of available BVMOs are limited, so that there is a high demand to expand on the diversity (Fürst et al. 2019). Moreover, most of the research with isolated enzymes investigated prokaryotic BVMOs (Fürst et al. 2019); therefore, eukaryotic BVMOs are lacking (Leipold et al. 2012).

While many BVMOs have been discovered by genome mining (Fürst et al. 2019), the potential of catalytic BVO activity found in the environments by function-driven screening is still underexplored. Therefore, this study aims to find a unique BVMO from environments. Acetone, the simplest ketone, was used as the only carbon source, expecting that the simplest substrate is the best to apply for further 
development. Besides being the simplest, the three acetone metabolic pathways, including BVO, carboxylation to form acetoacetate, and terminal hydroxylation to form acetol (1-hydroxy-2-propanone), have been reported (Hausinger 2007). Therefore, acetone was used as the only carbon source for screening microorganisms with a BVMO in this study, resulting in the isolation of two species of Fusarium, eukaryote, with a BVMO from soil samples. The BVMO from one of them, Fusarium sp. NBRC 109816 (FBVMO), was overexpressed in E. coli.

Then, FBVMO was immobilized to improve stability since one of the major obstacles for the utilization of BVMO for organic synthesis is its low stability. So far, BVMOs have not been successfully immobilized due to their low stability, except in a few cases (Cassimjee et al. 2014; Delgove et al. 2019). A thermostable cyclohexanone monooxygenase from Thermocrispum municipale (TmCHMO) was coimmobilized on an amino-functionalized agarose-based support with a glucose dehydrogenase (GDH) (Delgove et al. 2019). 2,5-Diketocamphane monooxygenase from Pseudomonas putida (2,5-DKCMO) was co-immobilized on controlled porosity glass (CPG) with two cofactor-reconverting enzymes (Cassimjee et al. 2014). Among enzyme immobilization methods (Liese and Hilterhaus 2013; Mohamad et al. 2015; Basso and Serban 2019; T.sriwong et al. 2021a), the protein-inorganic nanocrystal formation method is one of the simplest and most effective methods (Ge et al. 2012; Yin et al. 2015; Zhang et al. 2020). Lipase (Zhang et al. 2020), peroxidases (Ge et al. 2012; Yu et al. 2015; Altinkaynak et al. 2016), alcohol dehydrogenases (López-Gallego and Yate 2015; T.sriwong et al. 2020), and aldehyde dehydrogenase (T.sriwong et al. 2021b) have been immobilized by this method, achieving the improvement in the activity and/or stability. However, no BVMO has been immobilized by this method, to the best of our knowledge. Therefore, immobilization of FBVMO by the method was conducted in this study, resulting in a significant improvement in thermostability. Substrate specificity investigation revealed that both free and immobilized $F \mathrm{BVMO}$ were found to show catalytic activities not only for $\mathrm{BVO}$ of ketones to esters but also for oxidation of sulfides to sulfoxides. Furthermore, a preparative scale reaction using immobilized $F \mathrm{BVMO}$ was successfully conducted.

\section{Materials and methods}

\section{Reagents, materials, and apparatus}

Materials written in the Supplementary Information were used.

\section{Screening of microorganism using acetone as the only carbon source}

Environmental samples from soil, river, and ponds were collected, and diluted by $1.0-10^{5}$ times with sterilized water, and cultivated at $30^{\circ} \mathrm{C}$ and $250 \mathrm{rpm}$ in a liquid medium (Wiegant and De Bont $1980)$ at $\mathrm{pH} 7.0$ consisting of $\mathrm{K}_{2} \mathrm{HPO}_{4}(1.55 \mathrm{~g} / \mathrm{L}), \mathrm{KH}_{2} \mathrm{PO}_{4}(0.97 \mathrm{~g} / \mathrm{L}), \mathrm{NH}_{4} \mathrm{Cl}(2.0 \mathrm{~g} / \mathrm{L}), \mathrm{MgCl}_{2} \cdot 6 \mathrm{H}_{2} \mathrm{O}$ $(0.075 \mathrm{~g} / \mathrm{L}),\left(\mathrm{NH}_{4}\right)_{2} \mathrm{SO}_{4}(0.10 \mathrm{~g} / \mathrm{L}), \mathrm{NaCl}(0.39 \mathrm{~g} / \mathrm{L}), \mathrm{FeSO}_{4} \cdot 7 \mathrm{H}_{2} \mathrm{O}(0.010 \mathrm{~g} / \mathrm{L}), \mathrm{ZnSO}_{4} \cdot 7 \mathrm{H}_{2} \mathrm{O}(0.010 \mathrm{~g} / \mathrm{L})$, $\mathrm{MnSO}_{4} \cdot 5 \mathrm{H}_{2} \mathrm{O}(0.010 \mathrm{~g} / \mathrm{L}), \mathrm{KHCO}_{3}(0.50 \mathrm{~g} / \mathrm{L})$, and acetone (50-300 mM). Out of 300 samples, two microorganisms were able to grow with acetone as the only carbon source. They were identified as Fusarium sp. and Fusarium oxysporum Schltdl based on morphological tests (Supplementary Fig. 1) and 
115 ITS-5.8S rDNA sequencing. Fusarium sp. was deposited to the National Institute of Technology and

116 Evaluation (Tokyo, Japan) as Fusarium sp. NBRC 109816.

\section{Isolation of the gene}

Among the known genomic sequences of various Fusarium species, F. oxysporum $\mathrm{f}$. $\mathrm{sp}$. conglutinans race 254008 (accession number AGNF01000703.1) was selected by searching a genome with the highest homology with one of the most studied BVMO, CHMO from Acinetobacter sp. NCIMB9871 (Donoghue et al. 1976). To determine the sequence of FBVMO, four sets of primers (Supplementary Table 1) were constructed based on the sequence of AGNF01000703.1. for PCR using the genetic DNA of Fusarium sp. NBRC 109816 as a template. To remove the intron, two sets of primers (Supplementary Table 1) were constructed for PCR using the genetic DNA of Fusarium sp. NBRC 109816 as a template. The two PCR products were inserted into pUC19 and transformed into E. coli DH5 $\alpha$. Another set of primers (Supplementary Table 1) was used for PCR with pUC19-FBVMO as a template to obtain FBVMO gene to construct pET-21b(+)-FBVMO, which was transformed into $E$. coli BL21(DE3).

\section{Overexpression}

A single colony of the recombinant cells, BL21(DE3)-pET-21b(+)-FBVMO, was inoculated in LB medium $(4.0 \mathrm{~mL})$ with carbenicillin $(125 \mu \mathrm{g} / \mathrm{mL})$ at $250 \mathrm{rpm}$ at $37^{\circ} \mathrm{C}$ to an optical density at $600 \mathrm{~nm}$ $\left(\mathrm{OD}_{600}\right)$ reached $0.8-1.0$. The pre-cultured cells $(2.5 \mathrm{~mL})$ were transferred into LB medium $(250 \mathrm{ml})$ with carbenicillin $(125 \mu \mathrm{g} / \mathrm{mL})$, and cultivated at $250 \mathrm{rpm}$ at $37^{\circ} \mathrm{C}$ until $\mathrm{OD}_{600}$ reached 0.5-0.6. Then, IPTG $(0.2 \mathrm{mM})$ was added and cultivated at $250 \mathrm{rpm}$ at $18{ }^{\circ} \mathrm{C}$ for $18 \mathrm{~h}$. The cells were harvested by centrifugation at $10,000 \mathrm{G}$ for $5 \mathrm{~min}$ at $4{ }^{\circ} \mathrm{C}$, washed with $0.8 \% \mathrm{NaCl}$, and suspended in a sodium phosphate buffer ( $(30 \mathrm{~mL}, \mathrm{pH} 7.4,20 \mathrm{mM})$ containing imidazole (5 mM), PMSF (1 mM), and DTT (1 $\mathrm{mM}$ ). The mixture was sonicated at $100 \mathrm{~W}$ for $20 \mathrm{~min}$ at $0{ }^{\circ} \mathrm{C}$ and centrifuged at $15,000 \mathrm{G}$ for $30 \mathrm{~min}$ at 4 ${ }^{\circ} \mathrm{C}$, and the supernatant $(30 \mathrm{~mL}$ ) was used as a cell-free extract for further study.

\section{Purification}

The cell-free extract $(30 \mathrm{~mL})$ was loaded onto a HisTrap ${ }^{\mathrm{TM}} \mathrm{FF}$ crude equilibrated with a sodium phosphate buffer ( $\mathrm{pH} 7.4,20 \mathrm{mM})$ with PMSF $(0.2 \mathrm{mM})$, and DTT $(0.2 \mathrm{mM})$. The bound protein was eluted by the buffers with $5 \mathrm{mM}$ imidazole $(20 \mathrm{~mL}), 10 \mathrm{mM}$ imidazole $(10 \mathrm{~mL}), 20 \mathrm{mM}$ imidazole (10 $\mathrm{mL}$ ), $30 \mathrm{mM}$ imidazole $(5 \mathrm{~mL}$ ), and the $F \mathrm{BVMO}$ was eluted by the buffer with $70 \mathrm{mM}$ imidazole $(5 \mathrm{~mL})$ with PMSF $(0.2 \mathrm{mM})$, and DTT $(0.2 \mathrm{mM})$. The protein was concentrated by ultrafiltration using Amicon Ultra-4 10-K MWCO and used for further study. The protein concentration was measured by the Bradford method (Bradford 1976) using bovine serum albumin (BSA) as a standard. The purification steps are summarized in Supplementary Table 2. 


\section{Activity measurement of the free enzyme}

Cyclohexanone solution $(10 \mu \mathrm{L}, 0.1 \mathrm{M}$ solution with $10 \%$ diethylene glycol (final concentration $1 \mathrm{mM})$ ) and sodium phosphate buffer $(968 \mu \mathrm{L}, \mathrm{pH} 7.4,50 \mathrm{mM})$ were mixed, and then NADPH solution $(12 \mu \mathrm{L}, 10 \mathrm{mg} / \mathrm{mL})$, and purified enzyme $(10 \mu \mathrm{L}, 1.6-2.0 \mathrm{U} / \mathrm{ml})$ were added. Initial velocity was determined by following NADPH consumption at $340 \mathrm{~nm}$ for $3 \mathrm{~min}$. Activity assays were done at $25^{\circ} \mathrm{C}$ in duplicate in a $1.0 \mathrm{~mL}$ scale. One unit of enzyme is defined as $\mu \mathrm{mol}$ of NADPH produced in 1 min under the above conditions.

\section{Immobilization}

The purified FBVMO was immobilized with a similar method to our previous study (T.sriwong et al. 2020, 2021b). The phosphate-buffer saline (PBS) was prepared by dissolving $\mathrm{NaCl}(0.80 \mathrm{~g}), \mathrm{KCl}$ $(0.020 \mathrm{~g}), \mathrm{Na}_{2} \mathrm{HPO}_{4}(0.142 \mathrm{~g})$, and $\mathrm{KH}_{2} \mathrm{PO}_{4}(0.024 \mathrm{~g})$ in distilled water $(100 \mathrm{~mL})$ and adjusting $\mathrm{pH}$ to 7.4 with $\mathrm{HCl}(\mathrm{aq})$. The metal solutions (50 mM (final concentration $5 \mathrm{mM}$ ), $100 \mathrm{mM}$ (final concentration 10 $\mathrm{mM}$ ), $200 \mathrm{mM}$ (final concentration $20 \mathrm{mM}$ ), and $400 \mathrm{mM}$ (final concentration $40 \mathrm{mM}$ )) were prepared by dissolving $\mathrm{ZnSO}_{4}, \mathrm{MgSO}_{4}, \mathrm{MnSO}_{4}, \mathrm{CuSO}_{4}, \mathrm{FeSO}_{4}, \mathrm{NiCl}_{2}, \mathrm{CoCl}_{2}$, or $\mathrm{CaCl}_{2}$ in distilled water. PBS (350 $\mu \mathrm{L})$, the purified $F \mathrm{BVMO}(100 \mu \mathrm{L}, 1 \mathrm{U} / \mathrm{mL}$ in sodium phosphate buffer (50 mM, pH 7.4)), and metal solution $(50 \mu \mathrm{L})$ were mixed by gently turning it upside down, and incubated at $4{ }^{\circ} \mathrm{C}$ for $8 \mathrm{~h}$. The solution was centrifuged at $4{ }^{\circ} \mathrm{C}$ and 5,000 $\mathrm{G}$ for $5 \mathrm{~min}$. The precipitant was suspended in PBS and centrifuged at $4{ }^{\circ} \mathrm{C}$ and 5,000 G for 5 min twice, and suspended in PBS, giving immobilized FBVMO nanocrystal solution $(500 \mu \mathrm{l})$. The residual protein concentration in the supernatant was determined by the Bradford method (Bradford 1976), and the immobilization yield was calculated using equation (1).

$$
\text { Immobilization yield }(\%)=\frac{[\text { Protein }]_{\mathrm{I}}-[\text { Protein }]_{\mathrm{R}}}{[\text { Protein }]_{\mathrm{I}}} \times 100
$$

$[\text { Protein }]_{\mathrm{I}}=$ Initial protein concentration $(\mathrm{mg} / \mathrm{mL})$

$[\text { Protein }]_{\mathrm{R}}=$ Concentration of protein in the supernatant after the FBVMO nanocrystal formation and centrifugation $(\mathrm{mg} / \mathrm{mL})$

\section{Scanning Electron Microscope (SEM) analysis of immobilized FBVMO nanocrystal} FBVMO nanocrystal was analyzed by SEM with a similar method reported in our previous study (T.sriwong et al. 2020, 2021b). The FBVMO nanocrystal was washed with distilled water several times before being dried at room temperature.

\section{Activity measurement of the immobilized enzyme}

Cyclohexanone solution $(10 \mu \mathrm{L}, 0.1 \mathrm{M}$ solution with $10 \%$ diethylene glycol (final concentration $1 \mathrm{mM})$ ) and sodium phosphate buffer $(928 \mu \mathrm{L}, \mathrm{pH} 7.4,50 \mathrm{mM})$ were mixed, and then NADPH solution $(12 \mu \mathrm{L}, 10 \mathrm{mg} / \mathrm{mL})$, and immobilized $F$ BVMO solution $(50 \mu \mathrm{L})$ were added. Initial 
velocity was determined by following NADPH consumption at $340 \mathrm{~nm}$ for $3 \mathrm{~min}$. Activity assays were done at $40^{\circ} \mathrm{C}$ in duplicate in a $1.0 \mathrm{~mL}$ scale.

\section{Characterization of free and immobilized FBVMO}

Effects of $\mathrm{pH}$ and on their activities were investigated at $25^{\circ} \mathrm{C}$ using $50 \mathrm{mM}$ MES-NaOH buffer ( $\mathrm{pH} 5,6$ ), $50 \mathrm{mM}$ sodium phosphate buffer ( $\mathrm{pH} 7,7.5,8), 50 \mathrm{mM}$ Tris- $\mathrm{HCl}$ buffer ( $\mathrm{pH} \mathrm{8,} \mathrm{8.5,} \mathrm{9),} \mathrm{or}$ $50 \mathrm{mM}$ Gly-NaOH buffer $(\mathrm{pH} 9,10)$ with the methods described above. For $\mathrm{pH} 8$ and 9 , the averages of the activities in the two buffers are shown. Effects of temperature on their activity were investigated using sodium phosphate buffer ( $50 \mathrm{mM}, \mathrm{pH} 8.0$ ) with the methods described above. Thermostabilities of free and immobilized $F \mathrm{BVMO}$ were investigated by incubating at $40{ }^{\circ} \mathrm{C}$ and collecting the portion of the enzymes at $0,5,10,20,30,60,120$, and 300 min for activity measurement described above.

\section{Preparative-scale oxidation of cyclohexanone by the immobilized $F B V M O$} $F \mathrm{BVMO}$ nanocrystal solution $(1 \mathrm{~mL})$ prepared from $1 \mathrm{U}$ of free $F \mathrm{BVMO}$, heat treated Thermoplasma acidophilum glucose dehydrogenase solution $(1 \mathrm{~mL}, 1.95 \mathrm{U})$ prepared as reported previously (Are et al. 2021), cyclohexanone solution dissolving $100 \mathrm{mg}$ of cyclohexane in $1 \mathrm{~mL}$ of aqueous solution containing $10 \%$ of diethylene glycol, NADPH (50 mg), glucose solution ( $1 \mathrm{~mL}$ of $1 \mathrm{M}$ solution), and sodium phosphate buffer $(17 \mathrm{~mL}, 50 \mathrm{mM}, \mathrm{pH} 8.0)$ were mixed and incubated at $40{ }^{\circ} \mathrm{C}$ at $150 \mathrm{rpm}$ for 3 days. The reaction was repeated 5 times to convert $500 \mathrm{mg}(5.09 \mathrm{mmol})$ of cyclohexanone in total. The reaction mixtures were combined, and the product was extracted with diethyl ether $(25 \mathrm{~mL} \mathrm{x}$ 3), dried over $\mathrm{MgSO}_{4}$, evaporated under reduced pressure, purified by silica gel column chromatography (hexane : ethyl acetate $=3: 1$ ), and characterized by ${ }^{1} \mathrm{H}-\mathrm{NMR}$ analysis using $\mathrm{CDCl}_{3}$ as a solvent. The ${ }^{1} \mathrm{H}$ NMR spectrum was in agreement with that in literature (Omura et al. 2009). Yield $27 \%$ (157 mg, 1.37 mmol). ${ }^{1} \mathrm{H}-\mathrm{NMR}\left(400 \mathrm{MHz}, \mathrm{CDCl}_{3}\right): \delta 1.65-1.87$ (6H, m), 2.55-2.65 (2H, m), 4.19 (2H, t, $\left.J=4.7 \mathrm{~Hz}\right)$.

\section{Result and Discussion}

\section{Screening, overexpression, and purification of FBVMO}

Environmental samples from soil, river, and ponds were collected and cultivated using acetone (50-300 mM) as the only carbon source. Out of 300 samples, two microorganisms were able to grow with acetone as the only carbon. They were identified as Fusarium sp. and Fusarium oxysporum Schltdl based on morphological tests (Supplementary Fig. 1) and ITS-5.8S rDNA sequencing. Encouraged by the literature search showing the whole cell catalyzed BVO of 2-methylcyclohexanone by Fusarium sp. AP-2 (Kawamoto et al. 2008) and the whole-cell catalyzed BVO of alkyl-substituted hexanones by Fusarium oxysporum and Fusarium avenaceum (Ratu et al. 2009), we examined the presence of BVMO in the newly isolated Fusarium sp. and F. oxysporum Schltdl. Cyclohexanone was used as a substrate for the whole-cell reactions. $\varepsilon$-Caprolactone was successfully obtained in both reactions, suggesting the presence of a BVMO in both species. Fusarium sp. has higher activity than F. oxysporum Schltdl, so that Fusarium sp. was deposited to the National Institute of Technology and Evaluation (Tokyo, Japan) as Fusarium sp. 
NBRC 109816, and used for further study.

For the use as an efficient biocatalyst, it is necessary to express BVMO from Fusarium sp. NBRC 109816 (FBVMO), heterogeneously. Therefore, the gene encoding FBVMO was identified, amplified, and cloned in an expression vector, pET-21b (+), after the removal of the intron, leading to pET-21b (+)-FBVMO. The vector was transformed into E. coli BL21(DE3). His-tagged FBVMO was induced by IPTG and purified by Ni affinity chromatography by 17.4 fold in $41 \%$ yield (Supplementary Table 2). The DNA sequence and amino acid sequence are shown in Supplementary Figs. 2 and 3, respectively. In the deduced amino acid sequences, type I BVMO fingerprint FxGxxxHTxxW[P/D] (Fraaije et al. 2002; Rebehmed et al. 2013) and [A/G]GxWxxxx[F/Y]P[G/M]xxxD (Riebel et al. 2012) and two Rossmann fold domains with a GxGxx[G/A] motif were found.

\section{Immobilization of FBVMO and morphology study}

To improve the stability, FBVMO was immobilized by the organic-inorganic nanocrystal formation method according to our previous report (T.sriwong et al. 2020, 2021b). The purified $F \mathrm{BVMO}$ was mixed with a metal solution to give a catalytically active protein-inorganic nanocrystal. The kind and the concentration of the metal ion were optimized by investigating $5 \mathrm{mM}, 10 \mathrm{mM}, 20 \mathrm{mM}$, and $40 \mathrm{mM}$ of $\mathrm{Zn}^{2+}, \mathrm{Mg}^{2+}, \mathrm{Mn}^{2+}, \mathrm{Cu}^{2+}, \mathrm{Fe}^{2+}, \mathrm{Ni}^{2+}, \mathrm{Co}^{2+}$, and $\mathrm{Ca}^{2+}$. The activity of these nanocrystals toward the BaeyerVilliger oxidation of cyclohexanone is shown in Fig. 2. Nanocrystal formed using $10 \mathrm{mM}^{\circ} \mathrm{Ca}^{2+}$ showed the best activity among those tested, while high activity was observed in the nanocrystals from most of the ions except $\mathrm{Mn}^{2+}$.

Next, the stability of the nanocrystals formed under the optimum concentrations for each metal was investigated. The nanocrystals used for the activity assay were recovered by centrifugation as a precipitate, re-suspended in a buffer, and used for the activity assays (Fig 3(a)). To quantify the leakage of the protein from the nanocrystal, the protein concentration in the supernatant was measured. The amount of protein retained in the nanocrystal (immobilization yield) is shown in Fig 3(b). It was found that the FBVMO nanocrystal could be recycled up to 8 times with retained activity. The remaining activity after recycling largely depends on the kind of metal ions used for immobilization. The activity of the $10 \mathrm{mM}$ $\mathrm{Ca}^{2+}$ nanocrystal, showing the best activity for the $1^{\text {st }}$ usage, decreased dramatically by recycling, and its protein leakage was also obvious. On the other hand, while the activity of $20 \mathrm{mM} \mathrm{Cu}^{2+}$ nanocrystal was moderate for the $1^{\text {st }}$ usage (52\%), it did not decrease significantly for the $8^{\text {th }}$ usage $(42 \%)$, so as for the immobilization yield being $69 \%$ for the $1^{\text {st }}$ usage and $53 \%$ for the $8^{\text {th }}$ usage. Therefore, the best metal ion and its optimum concentration were determined to be $\mathrm{Cu}^{2+}$ and $20 \mathrm{mM}$.

The morphology study of $F \mathrm{BVMO}-\mathrm{Cu}^{2+}$ nanocrystal was conducted by SEM analysis (Supplementary Fig. 4). We found that the $F \mathrm{BVMO}-\mathrm{Cu}^{2+}$ nanocrystal forms a porous structure (Supplementary Fig. 4(b)), which could not be seen in the control copper (II) phosphate crystal without the enzyme (Supplementary Fig. 4 (a)). The high porosity of the sponge-like structure may cause the high activity of the $F \mathrm{BVMO}-\mathrm{Cu}^{2+}$ nanocrystal. 
First, the effect of $\mathrm{pH}$ on the activity of the free and immobilized FBVMO toward the oxidation of cyclohexanone was investigated. As shown in Fig. 4(a), similar results were obtained for the free and immobilized enzyme, showing the highest activity around $\mathrm{pH} 8.0-8.5$. Next, the effect of temperature on the activity of the free and immobilized $F \mathrm{BVMO}$ toward the oxidation of cyclohexanone was investigated. As shown in Fig. 4(b), the optimum temperature for the free and immobilized FBVMO were $30^{\circ} \mathrm{C}$ and $40^{\circ} \mathrm{C}$, respectively. The activity at $40^{\circ} \mathrm{C}$ increased significantly by immobilization. The free enzyme activity at $40{ }^{\circ} \mathrm{C}$ was $1.27 \mathrm{nmol} \cdot \mathrm{min}^{-1} \cdot \mathrm{mg}^{-1}$ protein, while the immobilized enzyme activity at $40{ }^{\circ} \mathrm{C}$ was $15.3 \mathrm{nmol} \cdot \mathrm{min}^{-1} \cdot \mathrm{mg}^{-1}$ protein. The immobilization improved the activity at $40^{\circ} \mathrm{C}$ by 12 times. Then, the thermostability of the free and immobilized FBVMO was investigated. As shown in Fig. 4(c), the free $F \mathrm{BVMO}$ had only $18 \%$ of the remaining activity after incubation for $5 \mathrm{~min}$ at $40{ }^{\circ} \mathrm{C}$, while $>90 \%$ of the activity of the immobilized $F \mathrm{BVMO}$ was retained after $5 \mathrm{~h}$ at $40{ }^{\circ} \mathrm{C}$. The thermostability of the FBVMO was significantly improved by immobilization. The nanocrystal formation method was proven as a promising approach for BVMOs immobilization. The confinement of enzymes in the nanocrystal may have fixed the unstable residue of the protein, as support materials act as a shell to protect the enzyme from harsh environments, including high temperatures in general immobilization methods (Hu et al. 2018; T.sriwong et al. 2021b). The successful result of immobilization of FBVMO, improving the thermostability, is remarkable since there are only a few examples (Cassimjee et al. 2014; Delgove et al. 2019) for the immobilization of BVMOs due to the low stability of BVMOs.

Substrate specificities of the free and immobilized FBVMO were investigated using varieties of ketones and sulfides. Both of the free and immobilized FBVMO successfully oxidized a wide range of ketones (Table 1, Entries 1-8), and sulfides (Table 1, Entries 9-13). In general, it was clear that the broad substrate specificity of the free $F \mathrm{BVMO}$ was greatly retained after immobilization. However, the difference in the relative activities between the free and immobilized FBVMO were also seen for the bulky substrates. The free enzyme exhibited about 3-5 times higher activities for cyclooctanone, 2pentylcyclopentan-1-one, 4-phenylbutan-2-one, and diphenyl sulfide (Table 1, Entries 3, 4, 8, 13). The change in the substrate preference by the immobilization is an intriguing phenomenon, since it was not observed for the case of other enzymes such as Geotrichum candidum aldehyde dehydrogenase (T.sriwong et al. 2021b). This might be caused by the subtle structural change of the enzyme by the immobilization or by the restriction in the substrate transfer to the active site of the immobilized enzyme due to the diminished flexibility of the residue at the entrance caused by the metal shell.

At last, a preparative scale reaction by the immobilized $F \mathrm{BVMO}$ was conducted using cyclohexanone as a substrate. The reaction proceeded smoothly, and the product was successfully

\section{Conclusion}

FBVMO was discovered from an environmental sample by the screening of microorganisms 
nanocrystal formation method, resulting in an improvement in thermostability. Both free and immobilized enzymes were characterized, and found to be versatile for both BVO and oxidation of sulfide. At last, preparative scale reaction of BVO of cyclohexane was successfully conducted.

\section{Author contributions}

M.T. and K.T. contributed equally to this work.

\section{Acknowledgement}

We would like to acknowledge Prof. Nobuo Nomura from Department of Human Sciences, Faculty of Human Sciences, Musashino University, Tokyo, Japan for the discussion regarding the isolation of FBVMO gene and overexpression, and Hiroumi Nemoto, Haruka Maeda, Tomofumi Tanabe, Ayana Hirukawa, Muhammad Maulana Ichsan from our laboratory for the related research. The authors are grateful to TechnoSuruga Laboratory Co., Ltd. Japan for the identification and examination of the microorganism. This work was supported by the Japan Society for the Promotion of Science (JSPS, KAKENHI Grant Number JP19K05560).

\section{References}

Altinkaynak C, Yilmaz I, Koksal Z, et al (2016) Preparation of lactoperoxidase incorporated hybrid nanoflower and its excellent activity and stability. Int J Biol Macromol 84:402-409. https://doi.org/https://doi.org/10.1016/j.ijbiomac.2015.12.018

Are KRA, Ohshima S, Koike Y, et al (2021) Enzymatic direct carboxylation under supercritical CO2. Biochem Eng J 171:108004. https://doi.org/https://doi.org/10.1016/j.bej.2021.108004

Basso A, Serban S (2019) Industrial applications of immobilized enzymes-A review. Mol Catal 479:110607. https://doi.org/https://doi.org/10.1016/j.mcat.2019.110607

Birolli WG, Lima RN, Porto ALM (2019) Applications of marine-derived microorganisms and their enzymes in biocatalysis and biotransformation, the underexplored potentials. Front Microbiol 10:. https://doi.org/10.3389/fmicb.2019.01453

Bong YK, Song S, Nazor J, et al (2018) Baeyer-Villiger Monooxygenase-Mediated Synthesis of Esomeprazole As an Alternative for Kagan Sulfoxidation. J Org Chem 83:7453-7458. https://doi.org/10.1021/acs.joc.8b00468

Bradford MM (1976) A Rapid and Sensitive Method for the Quantitation Microgram Quantities of Protein Utilizing the Principle of Protein-Dye Binding. 254:248-254

Bryliakov KP (2017) Catalytic Asymmetric Oxygenations with the Environmentally Benign Oxidants H2O2 and O2. Chem Rev 117:11406-11459. https://doi.org/10.1021/acs.chemrev.7b00167

Cassimjee KE, Kadow M, Wikmark Y, et al (2014) A general protein purification and immobilization 
method on controlled porosity glass: biocatalytic applications. Chem Commun 50:9134-9137. https://doi.org/10.1039/c4cc02605e

Chen YC, Peoples OP, Walsh CT (1988) Acinetobacter cyclohexanone monooxygenase: gene cloning and sequence determination. J Bacteriol 170:781-789. https://doi.org/10.1128/jb.170.2.781789.1988

Delgove MAF, Valencia D, Solé J, et al (2019) High performing immobilized Baeyer-Villiger monooxygenase and glucose dehydrogenase for the synthesis of $\varepsilon$-caprolactone derivative. Appl Catal A Gen 572:134-141. https://doi.org/10.1016/j.apcata.2018.12.036

Dong JJ, Fernández-Fueyo E, Hollmann F, et al (2018) Biocatalytic Oxidation Reactions: A Chemist's Perspective. Angew Chemie - Int Ed 57:9238-9261. https://doi.org/10.1002/anie.201800343

Donoghue NA, Norris DB, Trudgill PW (1976) The Purification and Properties of Cyclohexanone Oxygenase from Nocardia globerula CL1 and Acinetobacter NCIB 9871. Eur J Biochem 63:175192. https://doi.org/10.1111/j.1432-1033.1976.tb10220.x

Fordwour OB, Luka G, Hoorfar M, Wolthers KR (2018) Kinetic characterization of acetone monooxygenase from Gordonia sp. strain TY-5. AMB Express 8:1-13. https://doi.org/10.1186/s13568-018-0709-X

Fraaije MW, Kamerbeek NM, van Berkel WJH, Janssen DB (2002) Identification of a Baeyer-Villiger monooxygenase sequence motif. FEBS Lett 518:43-47. https://doi.org/10.1016/s00145793(02)02623-6

Franceschini S, Van Beek HL, Pennetta A, et al (2012) Exploring the structural basis of substrate preferences in Baeyer-Villiger monooxygenases: Insight from steroid monooxygenase. J Biol Chem 287:22626-22634. https://doi.org/10.1074/jbc.M112.372177

Fürst MJLJ, Gran-Scheuch A, Aalbers FS, Fraaije MW (2019) Baeyer-Villiger Monooxygenases: Tunable Oxidative Biocatalysts. ACS Catal 9:11207-11241. https://doi.org/10.1021/acscatal.9b03396

Fürst MJLJ, Savino S, Dudek HM, et al (2017) Polycyclic ketone monooxygenase from the thermophilic fungus Thermothelomyces thermophila: A structurally distinct biocatalyst for bulky substrates. J Am Chem Soc 139:627-630. https://doi.org/10.1021/jacs.6b12246

Ge J, Lei J, Zare RN (2012) Protein-inorganic hybrid nanoflowers. Nat Nanotechnol 7:428-432. https://doi.org/10.1038/nnano.2012.80

Hausinger RP (2007) New insights into acetone metabolism. J Bacteriol 189:671-673. https://doi.org/10.1128/JB.01578-06

Hu Y, Dai L, Liu D, et al (2018) Progress \& prospect of metal-organic frameworks (MOFs) for enzyme 
immobilization (enzyme/MOFs). Renew Sustain Energy Rev 91:793-801. https://doi.org/10.1016/j.rser.2018.04.103

Kawamoto M, Utsukihara T, Abe C, et al (2008) Biotransformation of ( \pm )-2-methylcyclohexanone by fungi. Biotechnol Lett 30:1655-1660. https://doi.org/10.1007/s10529-008-9729-y

Know GR (1993) The Baeyer-Villiger oxidation of ketones and aldehydes. In: Paquette LA (ed) Organic reactions. John Wiley \& Sons, Inc, pp 251-798

Koesoema AA, Standley DM, Senda T, Matsuda T (2020) Impact and relevance of alcohol dehydrogenase enantioselectivities on biotechnological applications. Appl. Microbiol. Biotechnol. 104:2897-2909

Kyte BG, Rouvière P, Cheng Q, Stewart JD (2004) Assessing the Substrate Selectivities and Enantioselectivities of Eight Novel Baeyer-Villiger Monooxygenases toward Alkyl-Substituted Cyclohexanones. J Org Chem 69:12-17. https://doi.org/10.1021/jo0302531

Leipold F, Rudroff F, Mihovilovic MD, Bornscheuer UT (2013) The steroid monooxygenase from Rhodococcus rhodochrous; A versatile biocatalyst. Tetrahedron Asymmetry 24:1620-1624. https://doi.org/10.1016/j.tetasy.2013.11.003

Leipold F, Wardenga R, Bornscheuer UT (2012) Cloning, expression and characterization of a eukaryotic cycloalkanone monooxygenase from Cylindrocarpon radicicola ATCC 11011. Appl Microbiol Biotechnol 94:705-717. https://doi.org/10.1007/s00253-011-3670-z

Liese A, Hilterhaus L (2013) Evaluation of immobilized enzymes for industrial applications. Chem Soc Rev 42:6236-6249. https://doi.org/10.1039/C3CS35511J

Liu C, Wen KG, Zeng XP, Peng YY (2020) Advances in Chemocatalytic Asymmetric Baeyer-Villiger Oxidations. Adv Synth Catal 362:1015-1031. https://doi.org/10.1002/adsc.201901178

López-Gallego F, Yate L (2015) Selective biomineralization of Co3(PO4)2-sponges triggered by Histagged proteins: efficient heterogeneous biocatalysts for redox processes. Chem Commun 51:87538756. https://doi.org/10.1039/C5CC00318K

Matsuda T (ed) (2017) Future directions in biocatalysis, 2nd editio. Elsevier, Amsterdam

Mohamad NR, Marzuki NHC, Buang NA, et al (2015) An overview of technologies for immobilization of enzymes and surface analysis techniques for immobilized enzymes. Biotechnol Biotechnol Equip 29:205-220. https://doi.org/10.1080/13102818.2015.1008192

Morii S, Sawamoto S, Yamauchi Y, et al (1999) Steroid monooxygenase of Rhodococcus rhodochrous: Sequencing of the genomic DNA, and hyperexpression, purification, and characterization of the recombinant enzyme. J Biochem 126:624-631. https://doi.org/10.1093/oxfordjournals.jbchem.a022494 
Nguyen Q-T, Mattevi A, Fraaije MW (2017) Chapter 6 - Expanding the Repertoire of FlavoenzymeBased Biocatalysis. In: Matsuda T (ed) Future Directions in Biocatalysis (Second Eition). Elsevier, Amsterdam, pp 119-133

Omura S, Fukuyama T, Murakami Y, et al (2009) Hydroruthenation triggered catalytic conversion of dialdehydes and keto aldehydes to lactones. Chem Commun 6741-6743. https://doi.org/10.1039/B912850F

Ratu B, Gładkowski W, Wawrze C (2009) Enzyme and Microbial Technology New aspects of the application of Fusarium strains to production of. 45:156-163. https://doi.org/10.1016/j.enzmictec.2009.04.008

Rebehmed J, Alphand V, de Berardinis V, de Brevern AG (2013) Evolution study of the Baeyer-Villiger monooxygenases enzyme family: functional importance of the highly conserved residues. Biochimie 95:1394-1402. https://doi.org/10.1016/j.biochi.2013.03.005

Rehdorf J, Kirschner A, Bornscheuer UT (2007) Cloning, expression and characterization of a BaeyerVilliger monooxygenase from Pseudomonas putida KT2440. Biotechnol Lett 29:1393-1398. https://doi.org/10.1007/s10529-007-9401-y

Riebel A, Dudek HM, De Gonzalo G, et al (2012) Expanding the set of rhodococcal Baeyer-Villiger monooxygenases by high-throughput cloning, expression and substrate screening. Appl Microbiol Biotechnol 95:1479-1489. https://doi.org/10.1007/s00253-011-3823-0

Sheldon RA, Woodley JM (2018) Role of Biocatalysis in Sustainable Chemistry. Chem Rev 118:801838. https://doi.org/10.1021/acs.chemrev.7b00203

T.sriwong K, Kamogawa R, Issasi CSC, et al (2021a) Geotrichum candidum acetophenone reductase immobilization on reduced graphene oxide: a promising biocatalyst for green asymmetric reduction of ketones. Biochem Eng J 108263. https://doi.org/10.1016/j.bej.2021.108263

T.sriwong K, Koesoema AA, Matsuda T (2020) Organic-inorganic nanocrystal reductase to promote green asymmetric synthesis. RSC Adv 10:30953-30960. https://doi.org/10.1039/d0ra03160g

T.sriwong K, Ogura K, Hawari MA, Matsuda T (2021b) Geotrichum candidum aldehyde dehydrogenaseinorganic nanocrystal with enhanced activity. Enzyme Microb Technol 150:109866. https://doi.org/10.1016/j.enzmictec.2021.109866

Wiegant WM, De Bont JAM (1980) A new route for ethylene glycol metabolism in Mycobacterium E44. J Gen Microbiol 120:325-331. https://doi.org/10.1099/00221287-120-2-325

Woo JM, Jeon EY, Seo EJ, et al (2018) Improving catalytic activity of the Baeyer-Villiger monooxygenase-based Escherichia coli biocatalysts for the overproduction of (Z)-11(heptanoyloxy)undec-9-enoic acid from ricinoleic acid. Sci Rep 8:1-11. 
https://doi.org/10.1038/s41598-018-28575-8

Wu S, Snajdrova R, Moore JC, et al (2020) Biocatalysis: Enzymatic Synthesis for Industrial Applications. Angew Chemie - Int Ed 2-34. https://doi.org/10.1002/anie.202006648

Yin Y, Xiao Y, Lin G, et al (2015) An enzyme-inorganic hybrid nanoflower based immobilized enzyme

\section{Supporting information}

452

Reagents, materials, and apparatus

453

Table 1 Primers used for PCR to construct BL21(DE3)-pET-21b(+)-FBVMO

Table 2 Summary of purification steps of FBVMO overexpressed in E. coli

Fig. 1 Microscopic observation images of Fusarium sp. NBRC 109816

Fig. 2 DNA sequence of $F \mathrm{BVMO}$ without intron

Fig. 3 Amino acid sequence of $F \mathrm{BVMO}$

Fig. 4 SEM images of crystals formed by mixing PBS and $\mathrm{CuSO}_{4}$ solution (a) without and (b) with FBVMO

Fig. $5{ }^{1} \mathrm{H}$ NMR spectrum of $\varepsilon$-caprolactone obtained by oxidation of cyclohexanone with immobilized

\section{Conflict of interest}

464 The authors declare that they have no conflict of interest.

\section{Figure legends}

466 Fig. 1 Baeyer-Villiger monooxygenase (BVMO) catalyzed reaction

467 Fig. 2 Effect of kind and concentration of metal ions for immobilization on residual activity. Activity before immobilization was set to $100 \%$. The activity was determined at $40{ }^{\circ} \mathrm{C}, \mathrm{pH} 7.4$.

Fig. 3 Effect of recycling of immobilized FBVMO on (a) activity and (b) immobilization yield The 

immobilization was set to $100 \%$.

Fig. 4 Effect of (a) $\mathrm{pH}$ and (b) temperature on oxidation activity of $F \mathrm{BVMO}$, and (c) thermo-stability of $F \mathrm{BVMO}$ at $40{ }^{\circ} \mathrm{C}$. Closed blue circle: immobilized $F \mathrm{BVMO}$, open red circle: free $F \mathrm{BVMO}$ (a) Activity at $\mathrm{pH} 8.0$ was set to $100 \%$ for free enzymes, and activity at $\mathrm{pH} 8.5$ was set to $100 \%$ for immobilized FBVMO. (b) Activity at $30^{\circ} \mathrm{C}$ was set to $100 \%\left(0.0192 \mu \mathrm{mol} \cdot \mathrm{min}^{-1} \cdot \mathrm{mg}^{-1}\right.$ protein) for free enzymes, and activity at $40^{\circ} \mathrm{C}$ was set to $100 \%\left(0.0153 \mu \mathrm{mol} \cdot \mathrm{min}^{-1} \cdot \mathrm{mg}^{-1}\right.$ protein $)$ for

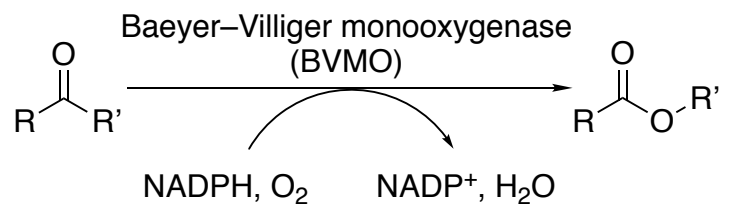

Fig. 1 Baeyer-Villiger monooxygenase (BVMO) catalyzed reaction

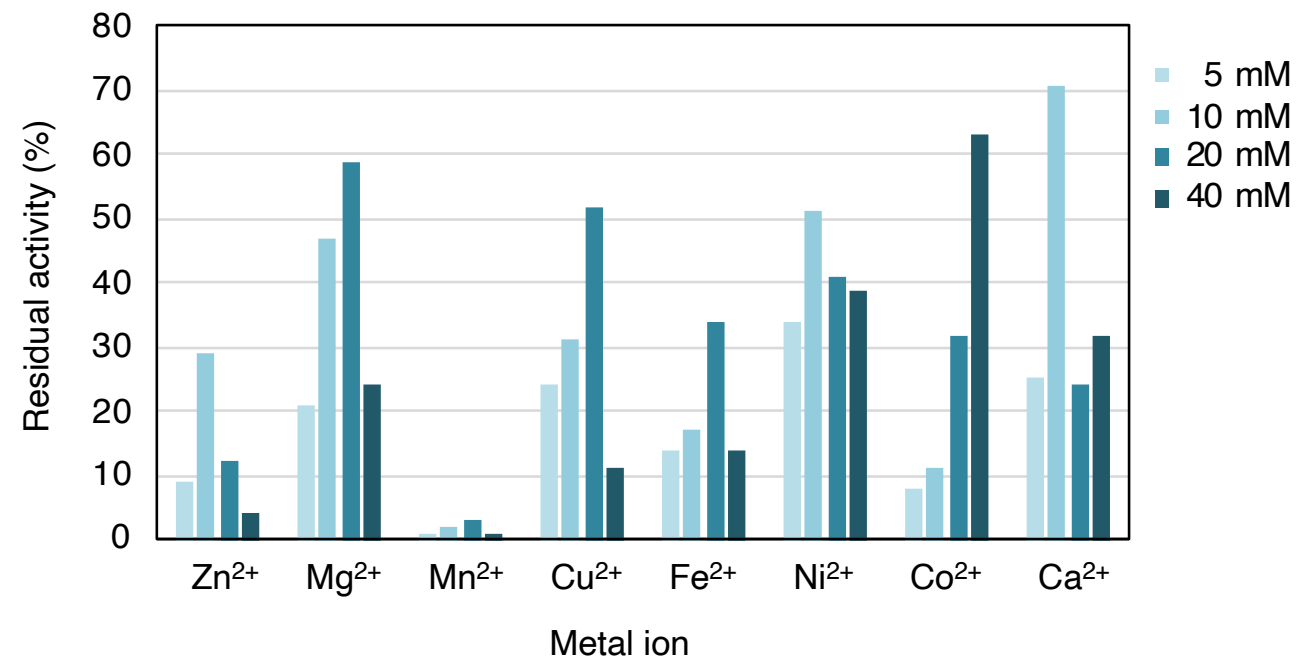

Fig. 2 Effect of kind and concentration of metal ions for immobilization on residual activity. Activity before immobilization was set to $100 \%$. The activity was determined at $40^{\circ} \mathrm{C}, \mathrm{pH} 7.4$. 
(a)

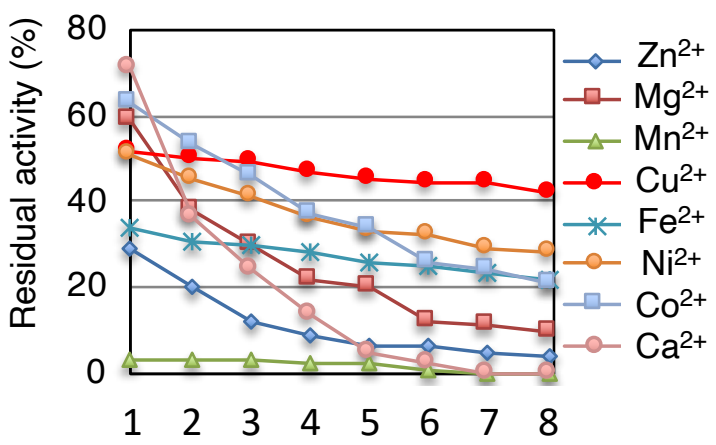

(b)

Recycling (time)

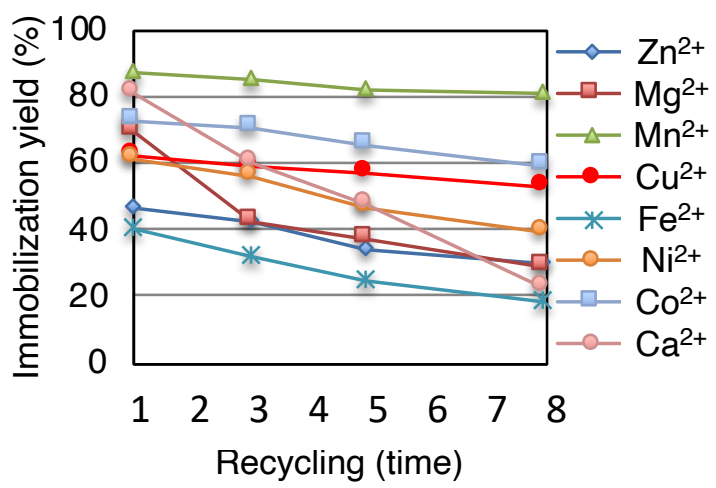

Fig. 3 Effect of recycling of immobilized FBVMO on (a) activity and (b) immobilization yield

The activity was determined at $40^{\circ} \mathrm{C}$ at $\mathrm{pH}$ 7.4. The optimum metal ion concentrations determined in Fig

4941 was used. Activity before immobilization was set to $100 \%$. Protein concentration before immobilization 495 was set to $100 \%$. 

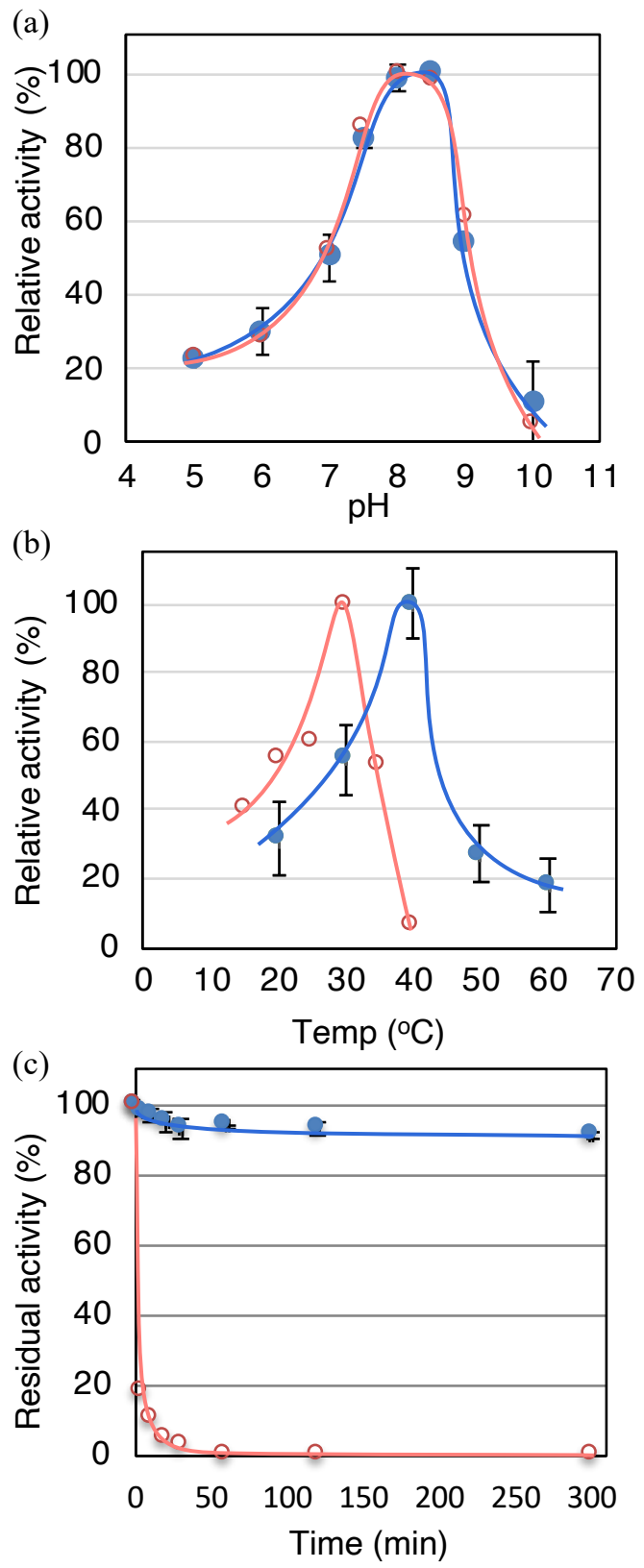

Fig. 4 Effect of (a) pH and (b) temperature on oxidation activity of $F \mathrm{BVMO}$, and (c) thermo-stability of $F \mathrm{BVMO}$ at $40^{\circ} \mathrm{C}$. Closed blue circle: immobilized $F \mathrm{BVMO}$, open red circle: free $F \mathrm{BVMO}$ (a) Activity at $\mathrm{pH} 8.0$ was set to $100 \%$ for free enzymes, and activity at $\mathrm{pH} 8.5$ was set to $100 \%$ for 500 immobilized $F$ BVMO.

(b) Activity at $30{ }^{\circ} \mathrm{C}$ was set to $100 \%\left(0.0192 \mu \mathrm{mol} \cdot \mathrm{min}^{-1} \cdot \mathrm{mg}^{-1}\right.$ protein $)$ for free enzymes, and activity at $40{ }^{\circ} \mathrm{C}$ was set to $100 \%\left(0.0153 \mu \mathrm{mol} \cdot \mathrm{min}^{-1} \cdot \mathrm{mg}^{-1}\right.$ protein $)$ for immobilized $F \mathrm{BVMO}$.

(c) The activities before the treatment were set to $100 \%$. 


\begin{tabular}{|c|c|c|c|}
\hline \multirow[t]{2}{*}{ Entry } & \multirow{2}{*}{ Substrate } & \multicolumn{2}{|c|}{ Relative activity (\%) } \\
\hline & & Free $F \mathrm{BVMO}$ & Immobilized $F \mathrm{BVMO}$ \\
\hline 1 & Cyclohexanone & 100 & 100 \\
\hline 2 & Cycloheptanone & 16 & 18 \\
\hline 3 & Cyclooctanone & 5.1 & 1.8 \\
\hline 4 & 2-Pentylcyclopentan-1-one & 83 & 18 \\
\hline 5 & Pentan-2-one & 5.1 & 4.6 \\
\hline 6 & Heptan-2-one & 2.7 & 2.8 \\
\hline 7 & 1-Cyclopropylethan-1-one & 3.0 & 2.2 \\
\hline 8 & 4-Phenylbutan-2-one & 83 & 18 \\
\hline 9 & Dimethyl sulfide & 2.8 & 3.2 \\
\hline 10 & Diethyl sulfide & 14 & 16 \\
\hline 11 & Dipropyl sulfide & 3.2 & 3.0 \\
\hline 12 & Methyl phenyl sulfide & 29 & 18 \\
\hline 13 & Diphenyl sulfide & 3.1 & 0.6 \\
\hline
\end{tabular}

510 The activities were determined under the standard assay conditions at $\mathrm{pH} 8.0$ in $50 \mathrm{mM}$ sodium phosphate 511 buffer at $25^{\circ} \mathrm{C}$ for the assay with the free $F \mathrm{BVMO}$ and $40^{\circ} \mathrm{C}$ for the assay with the immobilized $F \mathrm{BVMO}$. 512 The activities of free or immobilized FBVMO toward cyclohexanone were set to $100 \%$, respectively. 


\section{Supplementary Information}

\section{Immobilization of Baeyer-Villiger monooxygenase from acetone grown Fusarium sp.}

Michio Takagi, Kotchakorn T.sriwong, Ayaka Masuda, Nozomi Kawaguchi, Shusuke Fukui, Huong Le

Viet Lan, Dai-ichiro Kato, Takashi Kitayama, Mikio Fujii, Afifa Ayu Koesoema, Tomoko Matsuda

\section{Table of content}

Reagents, materials, and apparatus

Table 1 Primers used for PCR to construct BL21(DE3)-pET-21b(+)-FBVMO

Table 2 Summary of purification steps of FBVMO overexpressed in E. coli 2

Fig. 1 Microscopic observation images of Fusarium sp. NBRC $109816 \quad 2$

Fig. 2 DNA sequence of FBVMO without intron $\quad 3$

Fig. 3 Amino acid sequence of FBVMO $\quad 3$

Fig. 4 SEM images of crystals formed by mixing $\mathrm{PBS}$ and $\mathrm{CuSO}_{4}$ solution

(a) without and (b) with FBVMO $\quad 4$

Fig. $5{ }^{1} \mathrm{H}$ NMR spectrum of $\varepsilon$-caprolactone obtained by oxidation of cyclohexanone
with immobilized FBVMO

$\begin{array}{ll}\text { References } & 5\end{array}$

\section{Reagents, materials, and apparatus}

Chemicals were purchased from Nacalai Tesque (Kyoto, Japan), Tokyo Chemical Industry (Tokyo, Japan), or Wako (Tokyo, Japan) unless otherwise indicated. All reagents were used without purification. Restriction enzymes, DNA marker for Agarose gel electrophoresis, $\lambda$ DNA/HindIII Markers G1711, Pure Yield ${ }^{\mathrm{TM}}$ Plasmid Miniprep System, and Wizard SV Gel PCR Clean-Up System were purchased from Promega (USA). Ex Taq polymerase and In-Fusion HD Cloning Kit were purchased from Takara Bio (Shiga, Japan). Precision Plus Protein ${ }^{\mathrm{TM}}$ All Blue Standards, and protein concentration measurement reagent (Bradford reagent) were purchased from Bio-rad (USA). GenElute ${ }^{\mathrm{TM}}$ Plant Genomic DNA Miniprep Kit and 4-(2-hydroxyethyl)-1-piperazineethanesulfonic acid (HEPES) were purchased from Sigma Aldrich (USA). HisTrap ${ }^{\mathrm{TM}} \mathrm{FF}$ crude $(1 \mathrm{~mL})$ was purchased from GE Healthcare (Tokyo, Japan). Amicon Ultra-4 (10 k) was purchased from Merk Millipore (USA).

Experiments were done using Bio-shaker BR-43FL from Taitech (Nagoya, Japan), high speed centrifuge TOMY MX-301 from Tomy Seiko (Tokyo, Japan), Gen Amp PCR system 9700 from Applied Biosystems (USA), and insonator $201 \mathrm{M}$ from Kubota (Tokyo, Japan). Enzyme activity assays were performed on a UV-1900-UV-Vis spectrophotometer from Shimadzu (Kyoto, Japan). GC analysis was performed on a GC-14B equipped with FID detector and CP-Chirasil DEX CB column (Varian, $25 \mathrm{~m} \mathrm{x}$ $0.32 \mathrm{~mm}$, and $0.25 \mu \mathrm{m}$ film thickness). ${ }^{1} \mathrm{H}-\mathrm{NMR}$ analysis was performed on a Bruker Biospin AVANCE III 400 spectrometer at $400 \mathrm{MHz}$ in $\mathrm{CDCl}_{3}$. Morphological observation was done by Bench-top Scanning Electron Microscope (SEM) proX supplied by Phenom-World (Netherlands). 
Table 1 Primers used for PCR to construct BL21(DE3)-pET-21b(+)-FBVMO

\begin{tabular}{|c|c|}
\hline Purposes & Sequence \\
\hline \multirow{8}{*}{$\begin{array}{l}\text { Determination of } \\
\text { FBVMO sequence }\end{array}$} & Forward primer-1 (5'-GCAAAAGGTCCCGAACATAA- 3') \\
\hline & Reverse primer-1 (5'-ATGATGTGATGGCTGTCCAA-3’) \\
\hline & Forward primer-2 (5'-GTGATCTCGGTGATGGGAGT-3') \\
\hline & Reverse primer-2 (5'-GGAAGCAAGCAAAAGAGAGC-3') \\
\hline & Forward primer-3 (5'-CTTGCCCCAAGCATGGAC-3') \\
\hline & Reverse primer-3 (5'-GTCAAGGCCGAGAAGCTGAT-3') \\
\hline & Forward primer-4 (5'-CATGTCACAGCAATACGGAGA-3') \\
\hline & Reverse primer-4 (5'-GATATCATCCAACACGCCAAC-3') \\
\hline \multirow{8}{*}{$\begin{array}{l}\text { Removal of the intron } \\
\text { and construction of } \\
\text { pUC19-FBVMO }\end{array}$} & pUC19-BVMO forward primer \\
\hline & (5'-TCGGTACCCGGGGATCATGACCCCTTGTCCTGATTACG-3') \\
\hline & BVMO intron reverse primer \\
\hline & (5’-AACATCGAAGGCGTCTCCGACATGGC-3’) \\
\hline & BVMO intron forward primer \\
\hline & (5'-GGATACGCCTTCGATGTT-3') \\
\hline & pUC19-BVMO reverse primer \\
\hline & (5'-TCGACTCTAGAGGATCGTCACTTCAGAACGGTCTAAATCC-3') \\
\hline \multirow{4}{*}{$\begin{array}{l}\text { Construction of } \\
\text { pET-21b(+)-FBVMO }\end{array}$} & Insert forward primer \\
\hline & (5'-AAGGAGATATACATATGACCCCTTGTTCTGATTACG-3’) \\
\hline & Insert reverse primer \\
\hline & (5'-GTCATGCTAGCCATAAACGGTCTAAATCCTTTGTATCC-3') \\
\hline
\end{tabular}

Table 2 Summary of purification steps of FBVMO overexpressed in E. coli

\begin{tabular}{cccccc}
\hline Step & $\begin{array}{c}\text { Total protein } \\
(\mathrm{mg})\end{array}$ & $\begin{array}{c}\text { Total unit } \\
(\mathrm{U})\end{array}$ & $\begin{array}{c}\text { Specific } \\
\text { activity } \\
(\mathrm{U} / \mathrm{mg})^{\mathrm{a}}\end{array}$ & $\begin{array}{c}\text { Yield } \\
(\%)\end{array}$ & $\begin{array}{c}\text { Purification } \\
\text { fold }\end{array}$ \\
\hline Cell free extract & 1.50 & 1.91 & 1.27 & 100 & 1 \\
HisTrap FF crude & 0.0352 & 0.78 & 22.1 & 41 & 17.4 \\
\hline
\end{tabular}

${ }^{a}$ The specific activity was measured using $0.1 \%$ diethylene glycol to dissolve substrate, cyclohexanone, easily. The specific activity without using diethylene glycol was same as that with diethylene glycol.
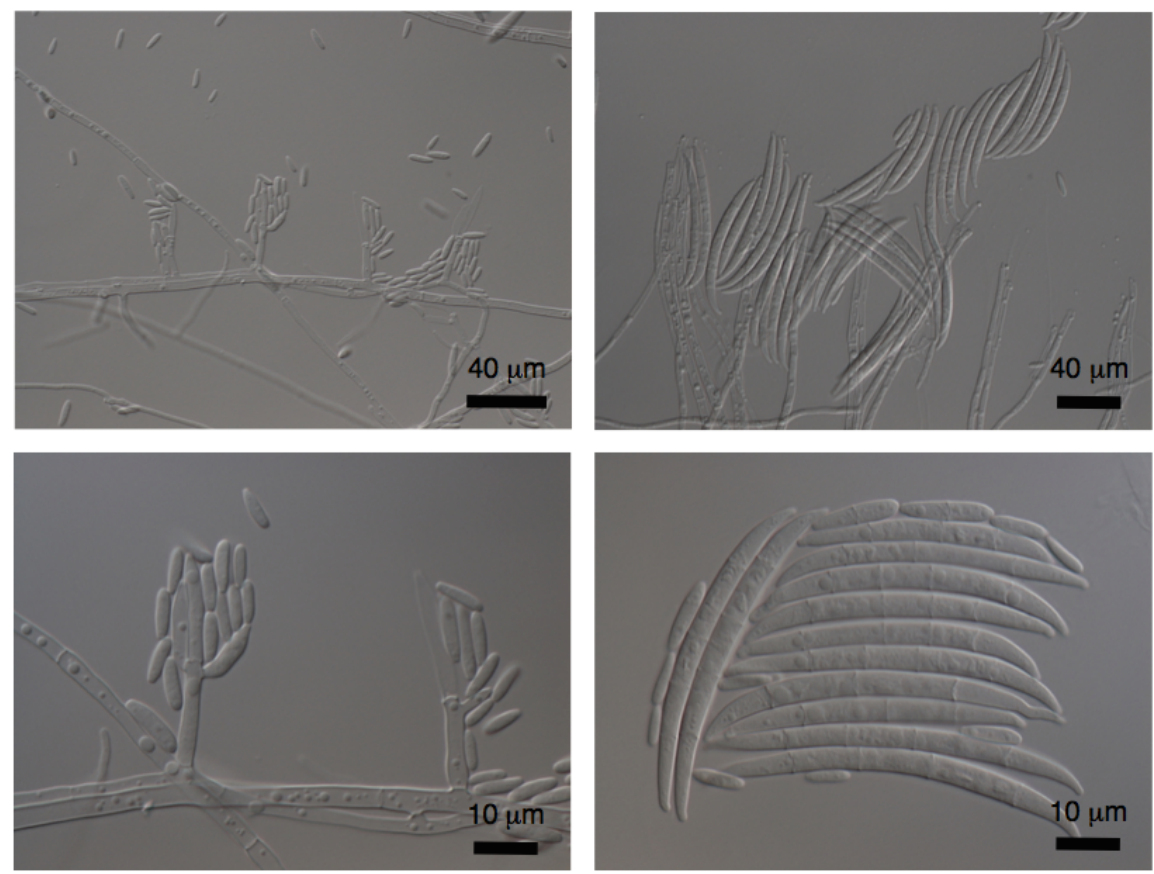

Fig. 1 Microscopic observation images of Fusarium sp. NBRC 109816 
ATGACCCCTTGTCCTGATTACGATGCTGTAGTAGTGGGAGCTGGCTTTGGTGGCATCTACATGT GCAAGAAGCTCGTGGACCAGGGCCTGTCTGTGAAGCTTATCGAGGTTGCGCCGGATGTTGGC GGCACTTGGTATTGGAATCGTTATCCGGGCGCCATGTCGGATACGCCTTCGATGTTGTATAGAT ACTCTTGGGACCTCGAAGATCTTCAGCAGTATTCATGGGAAAAGCAATACCTCCAACAACATG AGGTTTTGGCTTACCTACGGCATGTGGTTGATCGACATCAACTCCGTCAATATATGCAGTTCAA CGCTGAGATGAAAGCTGCCAACTGGGATCCAGACCACTCAAAATGGACTGTTGGTCTATCTTC TGGTCCGGATATCACATGTCGCTACTTGATCACCGCGATTGGGCTTCTTTCCAAGCAGAATTAT CCAGAAATCCGGGGATTGGATTCCTTCAAGGGCGAAATGTATCACACAGGGAGCTGGCCAGC GTCTTACGACTTCAAGAATAAGCGAGTCGGGGTTATTGGGAACGGATCGACCGGTGTTCAAG TCATTACCGCAATTGCAGATGAAGTAAAGCTTCTGCGTTCATTCCAGCGGCACCCGCAGTATG TTGTGCCTGCAGTCAATAGAGCGTTTCCTCCTGAAGATCGACGCGAGATTGACCGCCAATGGA ACGAGATCTGGAAGCAAGCAAAAGAGAGCATGTTTGGTTTTGGATTCGAGGAGAGTCAAACT CCTGCCTATAGTGTCACAGCAGAAGAGCGTGAAAAGATCTTCGAGAACGCCTGGCAAAAGG GTGGCGGCTTCAACTTTATGTTCGGAACCTTTTCCGACATCTCTTCTGACGAAGCGGCAAACA AAGAAGCAGCCGACTTTATCAAAAGAAAGATCCGCCAAATCGTCAAAGATCCTATCAAGGCC GAGAAGCTGATTCCCACAGAGCATTATGCTCGTCGTCCACTGTGTGATACGGGTTATTATGAG AAGTTCAACAGCCATAATGTGGATATCATTGATGTCAATGAGACTCCCATCACCGAGATCACG CCTAAGGGTGTTCGAACAAGCGACGGGGCCGAGTATGACCTCGATGTTCTTGTGTTTGCCAC AGGTTTTGATGCCGTAGATGGGAACTACAAGCGGATTCCGATCCAAGGTGTATCAAACAAGAC TCTCAAGGACTGTTGGGCTGATGGACCAGACTCATATCTCGGTATCTCTGTATCAGACTTCCCA AATCTCTTCATGATACTGGGTCCGAACGGTCCTTTTACAAATTTGCCCCCGACCATTGAGACCC AGGTTGAGTTTGTATCTGACATCATCCAACACGCCAATGAATCGGCACGTCAGAACGGCAAG AATCCTACTATTGAAGCAGAGCGAGAAGCGGTCCATGCTTGGAGCAAGATCTGTGACGAGCT TAGCGCAAACAGTTTATTTAGAAGGACAGATTCTTGGATTTTTGGTGCTAACGTAGCTGGGAA AAAGCCTTCGGTGCTCTTTTACTTTGGAGGTCTTGCAAACTATAGGAAGGCCTTGCAGGATTT GATCGATGATGGATACAAAGGATTTAGACCGTTTATGGCTA GCATGACTGGTGGACAGCAAAT GGGTCGGGGATCCGAATTCGAGCTCCGTCGACAAGCTTGCGGCCGCACTCGAGCACCACCAC CACCACCAC

Fig. 2 DNA sequence of $F \mathrm{BVMO}$ without intron green: sequence of $F \mathrm{BVMO}$,

yellow: sequence of restriction enzyme site, blue: sequence of His Tag, under line: sequence of T7 • Tag

MTPCPDYDAVVVGAGFGGIYMCKKLVDQGLSVKLIEVAPDVGGTWYWNRYPGAMSDTPSML YRYSWDLEDLQQYSWEKQYLQQHEVLAYLRHVVDRHQLRQYMQFNAEMKAANWDPDHSKW TVGLSSGPDITCRYLITAIGLLSKQNYPEIRGLDSFKGEMYHTGSWPASYDFKNKRVGVIGNGST GVQVITAIADEVKLLRSFQRHPQYVVPAVNRAFPPEDRREIDRQWNEIWKQAKESMFGFGFEES QTPAYSVTAEEREKIFENAWQKGGGFNFMFGTFSDISSDEAANKEAADFIKRKIRQIVKDPIKAEK LIPTEHYARRPLCDTGYYEKFNSHNVDIIDVNETPITEITPKGVRTSDGAEYDLDVLVFATGFDAV DGNYKRIPIQGVSNKTLKDCWADGPDSYLGISVSDFPNLFMILGPNGPFTNLPPTIETQVEFVSDII QHANESARQNGKNPTIEAEREAVHAWSKICDELSANSLFRRTDSWIFGANVAGKKPSVLFYFGG LANYRKALQDLIDDGYKGFRPF*

Fig. 3 Amino acid sequence of $F \mathrm{BVMO}$

blue: type I BVMO fingerprint; FxGxxxHTxxW[P/D] (Fraaije et al. 2002; Rebehmed et al. 2013) green: type I BVMO fingerprint; [A/G]GxWxxxx[F/Y]P[G/M]xxxD (Riebel et al. 2012) red: two Rossmann fold domains harboring a GxGxx [G/A] motif 
(a)

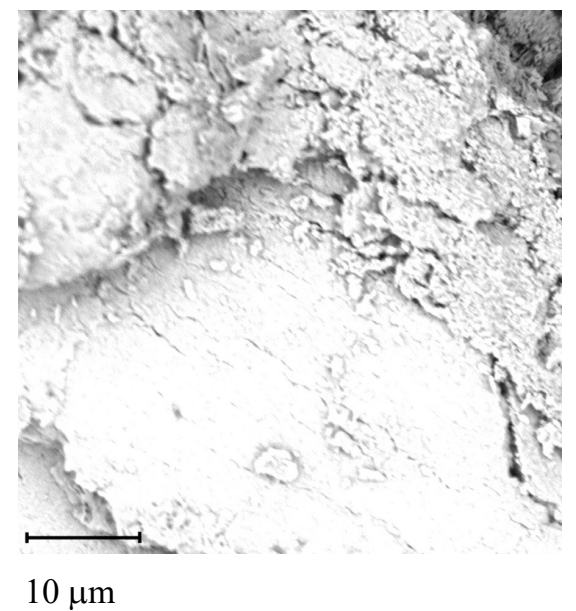

(b)

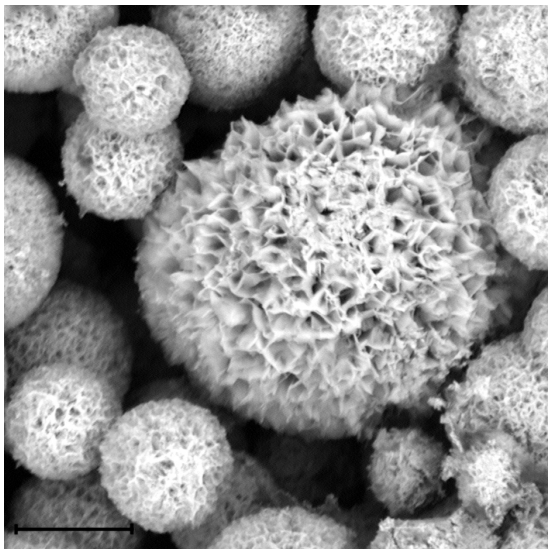

$10 \mu \mathrm{m}$

Fig. 4 SEM images of crystals formed by mixing PBS and $\mathrm{CuSO}_{4}$ solution (a) without and (b) with FBVMO

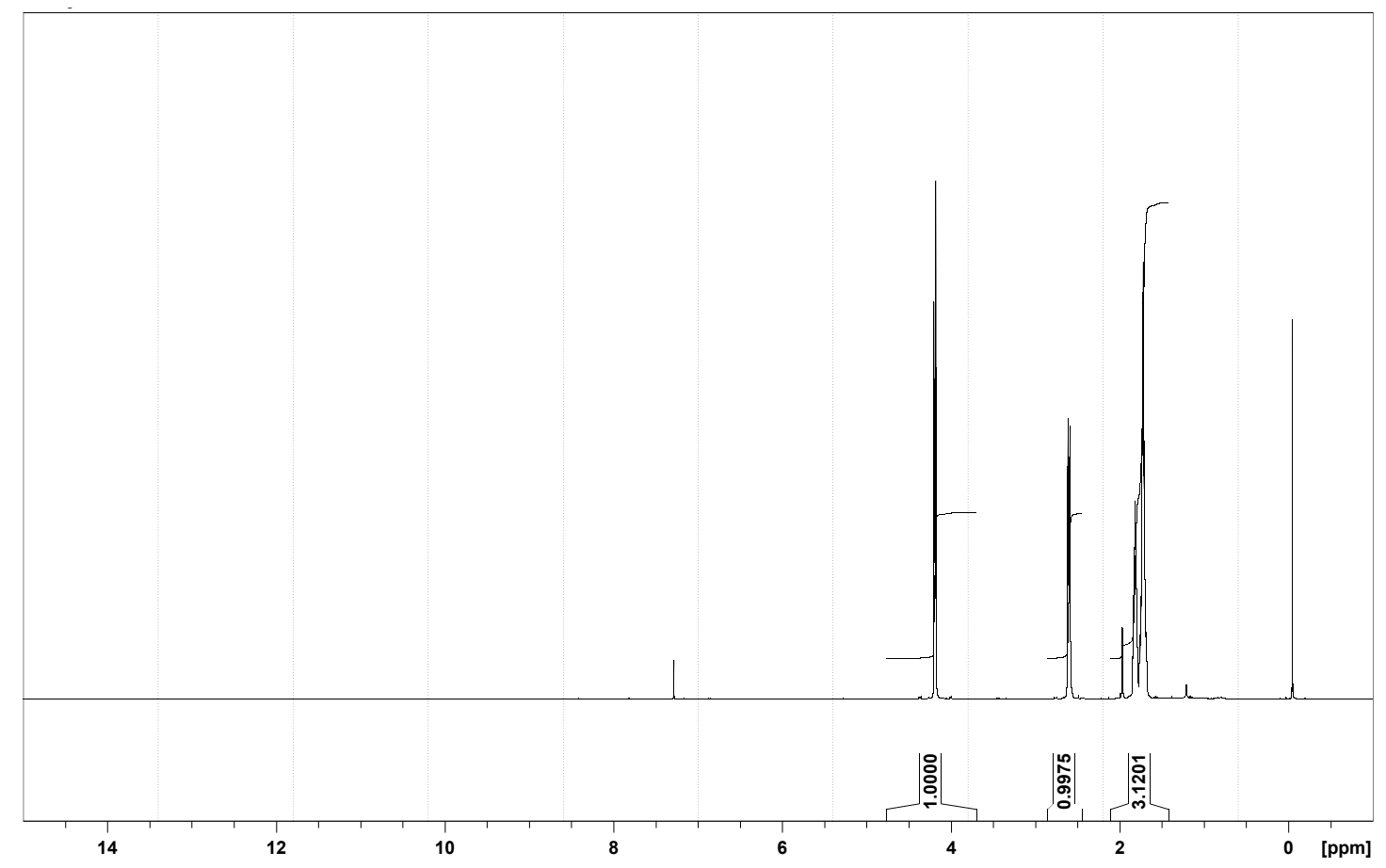

Fig. $5{ }^{1} \mathrm{H}$ NMR spectrum of $\varepsilon$-caprolactone obtained by oxidation of cyclohexanone with immobilized FBVMO 


\section{References}

Fraaije MW, Kamerbeek NM, van Berkel WJH, Janssen DB (2002) Identification of a Baeyer-Villiger monooxygenase sequence motif. FEBS Lett 518:43-47. https://doi.org/10.1016/s00145793(02)02623-6

Rebehmed J, Alphand V, de Berardinis V, de Brevern AG (2013) Evolution study of the Baeyer-Villiger monooxygenases enzyme family: functional importance of the highly conserved residues. Biochimie 95:1394-1402. https://doi.org/10.1016/j.biochi.2013.03.005

Riebel A, Dudek HM, De Gonzalo G, et al (2012) Expanding the set of rhodococcal Baeyer-Villiger monooxygenases by high-throughput cloning, expression and substrate screening. Appl Microbiol Biotechnol 95:1479-1489. https://doi.org/10.1007/s00253-011-3823-0 